\title{
Professional Ethics and Promotion Strategy of Technical and Tactical Police Teachers in Chinese Police Colleges
}

\author{
ZHOU Bo \\ Department of Police Skills and Tactics \\ Nanjing Forest Police College \\ Nanjing 210023, China \\ zhoubo@nfpc.edu.cn \\ JIA Chang-Zhi \\ Department of Police Skills and Tactics \\ Nanjing Forest Police College \\ Nanjing 210023, China \\ jiachangzhi@nfpc.edu.cn
}

\author{
ZHANG Fan* \\ Department of Police Skills and Tactics \\ Nanjing Forest Police College \\ Nanjing 210023, China \\ zhangfan@nfpc.edu.cn \\ ZHOU Wei-Fang \\ Department of Police Skills and Tactics \\ Nanjing Forest Police College \\ Nanjing 210023, China \\ zhouweifang@nfpc.edu.cn
}

\author{
LIU Yu-Xin \\ Department of Police Skills and Tactics \\ Nanjing Forest Police College \\ Nanjing 210023, China \\ liuyuxin@nfpc.edu.cn
}

\begin{abstract}
The teachers of police skills and tactics are both people's teachers and people's police, which requires that the teachers of police skills and tactics should have high quality and good professional ethics. This paper mainly adopts the methods of literature, interview and on-the-spot investigation method, discuss the promotion of policing tactics to raise teachers' occupation moral path from six aspects include special post with selfless dedication, loyal to the police badge with strict requirements, working based on cooperation to learn from each other, strict in discipline and taking the lead, studying police affairs with rigorous scholarship, formal appearance and ready to help others. Through the above strategies, we can improve the professional ethics of the police technical and tactical teachers in Police Colleges, in order to cultivate excellent talents and lay a solid foundation to the police.
\end{abstract}

Keywords-professional Ethics; police technical and tactical; police colleges; police spirit; professional quality

\section{INTRODUCTION}

At present and in the near future, the teachers of police skills and tactics at China's police colleges are and will be mostly non-police institutions graduates. They mainly graduate from normal universities and institutions of physical education, as well as transfer from professional sports teams or from the army. They do not systematically study the theories and professional ethics of public security education, lacking of skills and experience in the actual combat. Besides, they do not have deep understanding about the professional ethics for the teachers of police skills and tactics either.

Professional are produced in professional activities, referring to the sum total of ethical principles and moral standards that guide the professional behaviors formed in professional activities, as well as the corresponding moral values, moral sentiments and moral qualities. As the police officers, the teachers of police skills and tactics are on the front line to fight against illegal criminal activities [1]. At the same time, as teachers, they shoulder the responsibility of teaching and educating people. Therefore, the professional ethics for the teachers of police skills and tactics are closely combined with their dual role, forming a unique moral system.

\section{DISCUSS THE WAY TO IMPROVE THE PROFESSIONAL ETHICS OF POLICE SKILLS AND TACTICAL TEACHERS}

\section{A. Special post with selfless dedication}

The teachers of police skills and tactics should fully know and understand the general theories and knowledge for the major of police. In addition, they should conduct deep research 
on the courses they teach, which is incredibly tough and beyond imagination for non-professionals. They do not just teach the facts on the stage like teachers of literary, history and philosophy, nor do they train running and jumping like general PE teachers. For the teachers of police skills and tactics, in the teaching process, their every word and action is closely related to stopping the crime, cracking down on criminals as well as protecting people's lives and property. Any negligence may lead to huge losses [2]. Besides, the teachers' returns are often worse than the labor and their contribution to the society. Therefore, only when teachers at public security schools are not afraid of hard work and do not care about personal gains and losses, can they adhere to the ordinary and tough post of public security education and police training, to devote their effort to the objects of education and training, for the overall quality of the public security officers and for the social stability.

The special post of the teachers of police skills and tactics requires them to understand their occupation and realize their own value mentally. The teachers of police skills and tactics receive general wages and benefits, which requires them to face and accept the reality and have an objective knowledge of the surrounding environment and things. Besides, they are required to maintain good contact with the real environment, and truly recognize and fulfill their duties.

\section{B. Loyal to the police badge with strict requirements}

Loving the objects of education and training shows the loyalty of the teachers of police skills and tactics to public security education and police training. Teachers should devote the greatest enthusiasm to the objects of education and training, and serve them wholeheartedly [3]. Teachers should have sincere communication with objects of education and training based on friendliness and trust, to make them willing to accept their education and guidance.

The teachers of police skills and tactics should be concerned about all the objects of education and training and should not have prejudice on the underachievers. They are gardeners who should take good care of all seedling, rather than the talent scouts. The so-called "elite education", "the education of elimination" or "selective education" are not acceptable. The teachers of police skills and tactics should not only respect, trust and care the objects of education and training, but also be strict with them. Their love for the objects of education and training are emotional and also reasonable.

In public security schools, the relationship between the teachers and the objects of education and training is democratic and equal. Teachers should adopt correct methods of education and teaching with the attitude of equality, to promote the development in the thinking, academic progress as well as physical and psychological health of the objects of education and training.

\section{Working based on cooperation to learn from each other}

The means of labor for the teachers of police skills and tactics are personalized, while the modern education requires teachers to work closely with the colleagues of relevant subjects and to learn from each other so that they can jointly cultivate the professional personnel for police with a wide range of knowledge [4]. Some scholars have pointed out that learning to cooperate is one of the essential qualities to cultivate creative talents. As the teachers of police skills and tactics graduate from different majors with their own academic expertise, they should overcome the bad habits of scorning each other and refusing to make progress.

Due to the difference in the age, life experience, characters, ideas, hobbies and living habits, the teachers of police skills and tactics sometimes have some conflicts. As the teachers, they must understand and support each other, to form good relationships among the colleagues. When they have difference in opinion with others, they should learn to be good listeners and allow different opinions. Besides, they should take measures to make the minority and people with different opinions to fully show their viewpoints and discuss the problems calmly with them. Arbitrary decisions should not be made.

\section{Strict in discipline and taking the lead}

The teachers of police skills and tactics are the mirror for objects of education and training. Their words and deeds are the focus of the objects. Hence, the characteristics of personality, ideological level, cultural accomplishment and demeanor of teachers at police schools affect the objects of education and training unconsciously [5]. From the perspective of epistemology, the objects of education and training with certain understanding and experience at public security schools are always observing the teachers' actions [6]. The teachers' role of good example can never be replaced by any means of education. Therefore, the teachers of police skills and tactics must be highly disciplined and take the lead. They should be honest and down-to-earth whatever they do and wherever they are. Working in earnest is a long-term tough process of continuous transformation and improvement.

Being strict in discipline and taking the lead has requirements in all aspects for the teachers of police skills and tactics [7]. They should not only absorb the intelligence, emotion, world outlooks and so on contained in the subjects they teach, but also check their scope and level, to develop good morality and maintain elegant demeanor. The teachers of police skills and tactics should get rid of all bad habits.

\section{E. Studying police affairs with rigorous scholarship}

The teachers of police skills and tactics should "propagate the doctrine, impart professional knowledge and resolve doubts", to fulfill their duty of "being tireless in teaching" [8]. However, they must have deep understanding of the knowledge before making the students understood. So they should work hard and keep studious. Mr. Tao Xingzhi said: "Only when people are never contented with their study, can they be tireless in teaching" Only with rigorous scholarship, can they raise their level of knowledge and enrich their teaching contents as well as improve the quality of teaching so that they can cultivate the talents of actual combat with the courage to explore and the innovative spirit [9].

Police science involves natural sciences, social sciences and the humane studies. They must be down-to-earth for study. The teachers of police skills and tactics should develop realistic, meticulous and rigorous scholarship. China's police science is still in the stage of start-up and growth on the whole, which 
needs to be better developed with the joint effort of several generations. But the rush for quick results in today's education and research departments make the teaching and research of the teachers at police schools difficult to achieve breakthroughs. Therefore, the teachers of police skills and tactics must work hard with great concentration to lay the solid foundation and carry out in-depth research with independent thinking and aggressiveness, to deal with the problems in the police science in the attitude of "persistence".

\section{F. Formal appearance and ready to help others}

The teachers of police skills and tactics are teachers who wear uniforms and police ranks. They must follow strict discipline and be a model for others. The teachers of police skills and tactics should have proper conducts and strictly adhere to the relevant police regulations and rules, such as The People's Republic of China People's Police Law, Interior Service Regulations on People's Police of Public Security Organs, Uniform Administrative Regulations on People's Police of Public Security Organs and so on. Policing management is different from military management. Policing management takes cultivating qualified people's police as the goal, which is in line with the nature of public security organs and the requirement of tasks, namely the model of management education suitable for the characteristics of service. It reflects the uniform features of the management objectives, management tools, management methods and management systems [10].

Police colleges are the important base for cultivating the people's police, responsible for providing the talents of people's police for the public security organs. The police colleges implement policing management, for the purpose of cultivating qualified police officers through standardized management, based on the requirements on the people's police by the country [11]. The implementation of policing management is not decided blindly but required by the actual work of public security organs for the cultivation of people's police and borrowed from the military management of the army. Furthermore, the implementation of policing management has practical significance and important effects on the talent cultivation in police colleges [12]. If police colleges want to ensure the smooth implementation of policing management, they must make all the staff of the schools, especially the teachers of police skills and tactics, know clearly the significance for the implementation of policing management.

Ready to take up the cudgels for a just cause is the fine tradition of the Chinese nation and also the requirement by the professional nature of the people's police. The teachers of police skills and tactics, in any case, must carry forward the spirits of ready to take up the cudgels for a just cause, upholding justice, promoting the righteousness, stopping the unhealthy trend, and driving away evil, to take the lead in promoting the public security and the social morality. If the teachers of police skills and tactics can achieve these, they can not only get approved by the society, but also establish prestige among the objects of education and training, to appeal to others.

\section{CONCLUSION}

The training of police skills and tactics not only trains the ability, skills and tactics, but also exercises the law enforcement and the image of the people's police. Police colleges play an important role in cultivating reserve talents for public security, improving the quality of the police, strengthening the construction of public servants and conducting international communication of police report.

In short, the training of police skills and tactics for actual combat both trains the ability, skills and tactics, but also exercises the law enforcement and the image of the people's police. Police colleges play an important role in cultivating reserve talents for public security, improving the quality of the police, strengthening the construction of public servants and conducting international communication of police report. The teachers of police skills and tactics are responsible for the overall improvement of the police officers' actual combat quality. The cause they are engaged in is a kind of creative labor, with the duty to cultivate a new generation of loyal guards who punish the crimes and manage the social order as well as be dedicated, to solve problems for the people.

The teachers of police skills and tactics should both have the morality of people's teachers and the people's police. As the teachers, they should be dedicated to education and willing to be the helps, to teach and educate people, with tireless in teaching, diligent study and the insatiable desire to learn; they should also work in unity and close cooperation and achieve mutual development. As the people's police, they should have firmly stand and be selfless as well fearless; they should observe discipline and love the people, being honest and loyal to the facts; they should be open, straightforward as well as tenacious, and willing to devote their lives to the country. They should also strictly enforce the laws and serve people with enthusiasm. The dual ethics in the work require higher demands for the teachers of police skills and tactics than general teachers and police officers. In terms of the professional qualities, the dual ethics have stricter requirements and higher standards on the teachers of police skills and tactics.

\section{ACKNOWLEDGMENT}

This work was supported in part by the Project of the Fundamental Research Funds for the Central Universities under Grant LGZD201709, in part by the Project of China Postdoctoral Science Foundation under Grant 2017M611849, in part by Jiangsu Qing LAN Project under Grant 2017, and in part by Nanjing Forest police College Teaching Reform Project under Grant ZD17001 \& YB17001.

\section{REFERENCES}

[1] Hanyi-pu. Needs and ways to enhance the quality of teachers' Professional Academy. Journal of Outside school education in China: Theory, vol. 20, pp. 57-58, April 2011. (In Chinese)

[2] Xie Wei. The construction of personality and school teachers Iceberg Theory. Legal system and economy, vol. 10, pp. 43-44, May 2015. (In Chinese)

[3] Cong Xiang Hui. Research on teaching reform of PE course in Colleges and Universities Based on MOOC. Journal of sports science and Technology Bulletin, vol. 24, pp. 71-72, July 2016. (In Chinese) 
[4] Li Feng, Yan Gang. Model construction and promotion strategy of professional quality of teachers in Vocational Education. Education and Vocation, vol.15, pp. 23-27, August 2016. (In Chinese)

[5] Li jin-qi. Recognition of teachers' professional attributes and teachers' quality structure -- Based on the perspective of Teacher Professionalization. Journal of Guangzhou Sports University, vol. 32, pp. 48-53, March 2012. ( In Chinese)

[6] Wang Zhuo, Yang Jian-yun. New Annotation on Professional Quality of Teachers. Journal of EDUCATION SCIENCE, vol. 20, pp. 51-53, May 2004. (In Chinese)

[7] Chen Ping, Zhang Gui-chun. A summary of professional quality research of training teachers in Vocational School. VOCATIONAL \& TECHNICAL EDUCATION FORUM, vol. 8, pp. 11-14, January 2007. (In Chinese)

[8] Liu Chen fang. The Research and Practice of Youth Teachers' Academic Ability in Colleges. JOURNAL OF SOUTHWEST UNIVERSITY FOR
NATIONALITIES (HUMANITIES AND SOCIAL SCIENCE), vol. 28, pp. 212-216, June 2007. (In Chinese)

[9] Liang Qing. Reflection and improvement of professional ethics construction of teachers in Vocational Colleges. Vocational \& Technical Education Forum, vol.5, pp. 4-7, April 2015. (In Chinese)

[10] Qian Xiao-fang, Zhou Yan. Logical starting point and path choice of University Teachers' professional ethics construction. Journal of hinese Higher Education, vol. 21, pp. 28-31, March 2012. ( In Chinese)

[11] Miao rui-lan. Crisis in situation: the system trap of improving teachers' professional ethics. Journal of Guangzhou Sports University, vol. 6, pp. 108-112, June 2017. ( In Chinese)

[12] Qin Fei, Sun Bei. Characteristics and Enlightenment of British and American police professional accomplishment education. Journal of Gansu Police Academy, vol.13, pp. 73-76, May 2015. (In Chinese) 